\title{
Effective Use of Foreign Debt, the Case for Turkey
}

\author{
S. Cem Karaman (Corresponding author) \\ Department of Economics, Turgut Ozal University \\ Ayvali Mah., Gazze Cad., No:7, 06010, Ankara, TURKEY \\ Tel: 90-(312)-551-5338Ｅ-mail: ckaraman@turgutozal.edu.tr
}

\author{
Received: April 7, 2015 Accepted: May 25, 2015 Published: September 29, 2015 \\ doi:10.5296/ijssr.v3i2.7086 URL: http://dx.doi.org/10.5296/ijssr.v3i2.7086
}

\begin{abstract}
An advanced financial system is regarded as a hallmark of development. Lending or borrowing money, or debt, plays a vital role in an economy. But just like any other economic decision, borrowing requires a thorough analysis of contingencies. Debt may lead to prosperity through sound investment, or it may overwhelm firms/people when not used properly. In today's circumstances, borrowing from world financial markets is easier than ever before. In this paper, the possibility of foreign borrowing helping Turkey to improve its macroeconomic variables of GDP, consumption, government spending, investment, exports and current account balance is explored. We look for cointegration relationships between various foreign debt variables classified as public or private foreign debt; short-term or long-term foreign debt, and various macroeconomic variables. Later, the variables studied are tested to see if there are any statistically causal relationships between them. The following results are found: short-term foreign debt is not cointegrated with any of the macroeconomic variables when long-term foreign debt is cointegrated with some of them; private foreign debt is more effective than public foreign debt on macroeconomic variables. Whilst Turkey is critically dependent on foreign borrowing in financing its current account deficit, its current account balance is not cointegrated with any of the foreign debt data. Public foreign debt precedes government spending where private foreign debt follows private sector spending. This is interpreted as a sign that the private sector is more careful with its borrowing decisions than the government since its spending, which is procyclical with the business cycle, is leading its borrowing.
\end{abstract}

Keywords: Debt, cointegration, foreign borrowing, Turkish economy, debt-driven growth JEL Classification: E22, F34 


\section{Introduction}

\subsection{Borrowing}

A well-developed financial market being essential for growth is an established economic fact. Financial markets facilitate transfer of funds from people with surplus savings to people and firms who are in need of financing their activities. People and firms need to borrow funds for various reasons, like sustaining economic viability, maintaining a continued cash flow, expansion and many more. But this does not make borrowing money an instrument without any drawbacks. In the end, many economic crises are the outcomes of excessively borrowed money.

The 2008 global financial crisis started with subprime borrowers defaulting on their debts. This triggered a massive sell-off of financial assets which eventually derailed the whole economy. It was people's dream to own a house and establish a micro dynasty through their own property. Decisions made without careful analyses of financial competencies, not only for people who borrowed money but for those who lent money as well, pushed people into conditions they had never thought of. People ended up losing their homes, and banks were left with many so-called toxic assets. Although the United States government bailed the banks out, average citizens were less fortunate with the consequences of their wrong decisions. Every decision requires a careful examination of the conditions and a good judgment. There is no single rule-of-thumb that will work in every case. The facts that people are short-sighted and go after quick fixes make the decision process more complicated. Therefore, borrowing decisions are double-edged swords. They can elevate people to prosperity or plunge them into ruin and destruction.

Another example to the perils of borrowing is microfinance. When it was first introduced, it was promoted as a "fashionable, cure-all for most non-governmental organizations" ; whereby later on, it is observed that it makes people more vulnerable to the abuses of different borrowing practices (Ahmad, 2003). People started borrowing, or lenders were allowed to lend, for purposes other than a good investment, like a big cultural wedding. Long-term yields of such ventures are very questionable, at best. People were left under the burden of debt without a good investment with which to pay it back. The social consequences of such debt ensued, like psychological problems leading up to suicides ${ }^{2}$.

There are a number of reasons why people take poor financial decisions. Sometimes ambitious expansion decisions without a careful analysis of the cash-flow map cause firms to go bankrupt, (Peacock, 2000). Sometimes the immediate pleasure of consumption blinds people to the realization of what may come in the near future. One of the most important Keynesian economists of the twentieth century, Hyman Minsky, explains human behavior as a swing: "A fundamental characteristic of our economy, is that the financial system swings between robustness and fragility and these swings are an integral part of the process that generates business cycles" (Minsky, 1974). In good times, people keep borrowing money

\footnotetext{
1 From Ahmad (2003).

2 A good discussion on the aftermaths of microfinance is Dichter, Harper, and Action (2007).
} 
with the perception that prices will follow their everyday trends, which eventually incites economic bubbles. When the other end of the swing is reached, the Minsky moment, trends are broken and prices fall pretty quickly. At that moment, people are overwhelmed beneath their debt and they start selling their assets, which triggers a sell-off in the whole economy.

\subsection{Borrowing from International Financial Markets}

Integration of world financial markets after 1980's, with major advancements in computer and data transmission technologies, made big impacts on developing countries' economic growth paths. With the innovations made in this period, it was possible to conduct real-time and substantial capital transfers across continents (Went, 2000). Thereafter, countries were not limited by their domestic savings in financing their development needs. But it was not until the 2000's that there were substantial drops in the cost of borrowing money from international financial markets. With advanced technology and lower global interest rates, it was possible to borrow not only with ease, but also with lower costs.

The time period after the United States' 2001 economic crisis was a remarkable period that had long-lasting financial consequences. The fear of adverse outcomes, like the ones during the 2001 crisis, impelled the policymakers of the time, primarily the head of the Federal Reserve Alan Greenspan, to pursue expansionary monetary policies of low interest rates. Together with a global savings glut (Bernanke, 2005), the world's financial conditions gave an opportunity to many developing countries to draw-in low-cost capital from international financial markets. Turkey, like countries with similar economies, enjoyed this period of prosperity (Karaman \& Can, 2014). With the availability of easy credit, the total Turkish foreign real debt increased fourfold between 2001 and 2013. The private sector was leading the race to borrow money where the government was more reluctant in borrowing. It was not uncommon to come across people who think that this level of foreign debt is unsustainable for Turkey (Bulutay, 2015), but Turkey kept borrowing.

Low-cost borrowing from international financial markets provided not only growth to developing countries, but also economic and political stability. Borrowing from international financial markets depends on internal factors, like political stability and expected return rates; and external factors like global interest rates and worldwide excess funds. Although internal factors are important, the major determinant for the direction of capital in world financial markets is the low interest rates in the developed world. The average real interest rate of 10-year U.S. treasury bonds from 1982 to 1991 was 5.57\%, whereby from 2004 to 2013 it was only $1.11 \%{ }^{3}$. Even if capital would prefer developed countries to land, the rock-bottom interest rates in these countries in the 2000's allowed developing countries to finance their growth from international financial markets.

The question remains as to what is accomplished with this borrowed money. In this paper, the answer to this question is explored by classifying Turkish foreign debt and Turkish macroeconomic variables into subcategories and then looking for statistical trends, if any two

\footnotetext{
3 10-year Treasury bond rates and U.S. consumer price index (CPI) data are obtained from Federal Reserve Economic Data (FRED) of Federal Reserve Bank of St. Louis.
} 
variables from these two subcategories are cointegrated. Existence of a long-run cointegration relationship between a debt variable and a macroeconomic variable will tell us a story about how the borrowed money has been used.

\subsection{Theory of Debt}

Sovereign debt and its consequences are among the most heated political discussions of our time. Many countries' swelling debt levels generate debates in the news outlets and in academia. Although, Ricardian equivalence states that consumers are forward looking and therefore government's purchasing decisions have no effect on the economy, the theory requires some unrealistic assumptions (Seater, 1993). The empirical evidence for Ricardian equivalence is also week (Bernheim, 1988).

Nevertheless, countries pursue fiscal policies that lead to unsustainable levels of debt. Perpetual unbalanced government budgets expand public debt to high levels such that only a crisis can end these governments' spending spree. An economic crisis has welfare implications for the whole country and they are numerous. Typically, the value of the local currency falls, which increases the cost of foreign goods. Consequently, this distorts the country's capital account balance. Firms and financial institutions with foreign currency denominated debt are affected worse with the fall in the value of the local currency. Deterioration in financial positions increases the number of bankruptcies which subsequently prevents the best use of capital with loss of information and loss of long-term relationships (Romer, 2011).

Taking a loan is essentially borrowing against future income. Providing unsecured loans involves some amount of risk for the lenders. Adverse selection, the term for individuals/firms knowing more about their own private financial conditions than the outsiders, is always an issue for lenders. Even though lenders collect information about the borrower in many different ways to overcome this asymmetric information problem, accountants still have ways to portray a different image of the true financial circumstances (Azariadis, 1993). The Greek debt crisis is a recent example to such a problem. With the help of some global financial service providers, the Greek government was able to hide its true financial status through financial "jiggerly-pokery" (Conway, 2010).

\section{Public vs. Private Foreign Debt}

The first decade of the $21^{\text {st }}$ century was a notable period for Turkey, when it enjoyed political stability and steady economic growth ${ }^{4}$. There is another feature of this period worth mentioning. In this decade, the Turkish government followed policies that would reduce its public debt. Despite the fact that money was cheaply available in world markets, the Turkish government decreased its total debt. Fiscal discipline, privatization and opening public land to construction generated extra revenue that allowed the government to live by its means. Figure 1 shows the change in public debt's relative weight in Turkey's total foreign debt. Whilst the private foreign debt steadily increased after the 2001 economic crisis of Turkey,

\footnotetext{
4 The period after the 2001 banking crisis.
} 
the public foreign debt decreased during this period ${ }^{5}$.

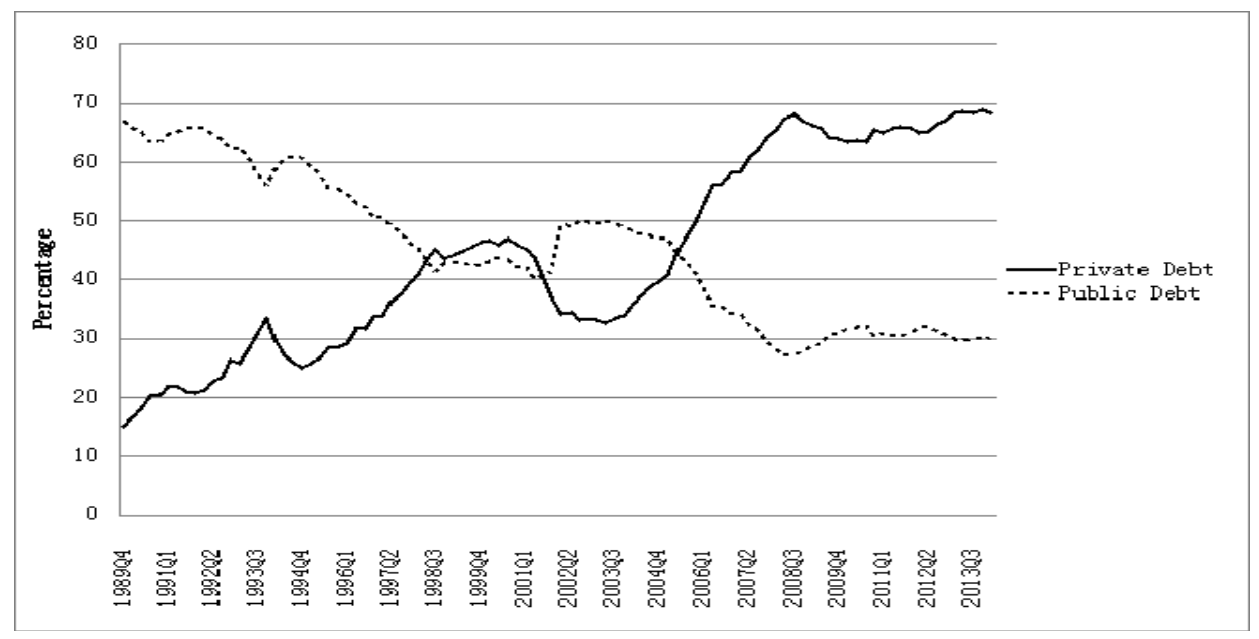

Figure 1. Turkish Foreign Debt

Turkish citizens enjoyed the benefits of low global interest rates by reducing their savings rate and increasing their consumption. Commercial banks adapted to the new conditions of the 2000's, from making money by lending money to the government in the 90's (Bredenkamp, Josefsson, \& Lindgren, 2009) to making money by lending money to people. With such changes, the middle class people of Turkey had the opportunity to borrow money and increase their consumption, which definitely improved Turkish gross domestic product (GDP) as shown below.

In the 2000's, foreign borrowing simply replaced domestic savings in Turkey. The domestic savings rate had already been in decline since the early 1980's, but with the lowest global interest rates available, Turkish entrepreneurs and investors did not need domestic savings anymore. In Table 1, the savings rate of Turkey is reported with comparable countries.

\footnotetext{
5 Although Turkey's public debt to GDP ratio, $45 \%$ as of 2012 , is not as high as many other developing and developed countries, debt payments in the total budget are still substantial: $13.7 \%$ of the budget was interest payments in 2012 .
} 
Table 1. Savings rates of the "Fragile Five"6 and some other developing countries

\begin{tabular}{lrrrrr}
\hline & $\mathbf{1 9 9 0}$ & $\mathbf{1 9 9 5}$ & $\mathbf{2 0 0 0}$ & $\mathbf{2 0 0 5}$ & $\mathbf{2 0 1 2}$ \\
\hline Brazil & 18.9 & 15.5 & 14.0 & 17.3 & 14.6 \\
Germany & 24.8 & 22.6 & 22.1 & 23.6 & 26.3 \\
East Asia \& Pacific (developing only) & 36.6 & 39.0 & 35.2 & 44.1 & 46.6 \\
Europe \& Central Asia (developing only) & N.A. & 20.5 & 18.6 & 18.2 & 17.7 \\
Indonesia & 28.1 & 28.1 & 25.0 & 26.0 & 30.7 \\
India & 23.1 & 26.1 & 25.0 & 33.7 & 30.3 \\
Latin America \& Caribbean (developing only) & 19.5 & 16.9 & 17.7 & 20.6 & 19.0 \\
Turkey & 21.6 & 21.7 & 17.9 & 15.6 & 14.2 \\
South Africa & 19.1 & 16.5 & 15.8 & 14.5 & 14.2 \\
\hline
\end{tabular}

Source: World Bank Database

As can be seen in Table 1, Turkey, together with South Africa, had the lowest savings rate in the group in 2012. Since Turkey borrowed from international financial markets to make up the deficiency in its savings, its foreign debt stock rose steeply. Figure 2 is about Turkey's total foreign debt stock ${ }^{7}$. There is also an empirical study on the inverse relationship between Turkish domestic savings rate and its foreign financing by Şanlı and Aksöz (2014).

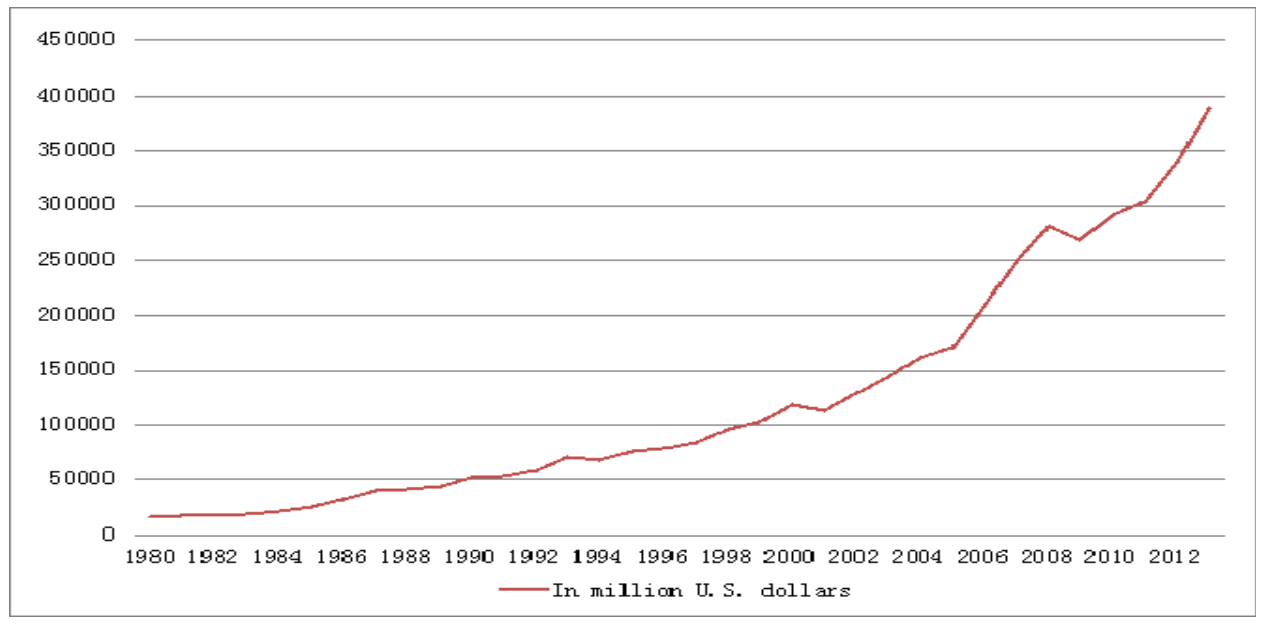

Figure 2. Turkey's Total Foreign Debt Stock

\footnotetext{
6 The "Fragile Five" name was given by a research analyst at Morgan Stanley, classifying these countries with their ambitious growth policies financed by foreign capital (Thomas, 2014). These countries are Turkey, India, Indonesia, South Africa and Brazil.

7 The figure is taken from Karaman (2015).
} 
It is of interest to know how this foreign debt has been spent and to find out about its effects on the economy, which is done in the following sections. The next section is about data and how it is tested. The section on cointegration follows, which shows long-run relationships between foreign debt data and various macroeconomic variables. After the cointegration analyses, statistically-causal relations between the two groups of variables are explored. In the last section, the paper is concluded with final thoughts on foreign debt, and future research on the topic is suggested.

\section{The Analysis}

The variables studied are in two groups: the first group is foreign debt data in various categories, and the second group consists of macroeconomic variables that would potentially be affected by the use of foreign debt. Foreign debt can be long-term or short-term. It can be public debt, the debt of the government, or it can be private debt, the debt of people and businesses. In this paper, instead of debt in general, only foreign debt is analyzed. In this way, the effects of foreign borrowing on domestic macroeconomic variables are explored. The macroeconomic variables that are studied are GDP, consumption, government spending, total investment, public investment, private investment, exports and current account balance. A matrix is built with variables from these two categories and the relationships between them are reported. In total, 48 mutual relationships are examined. All results are presented in tables categorized according to the maturity or the ownership of foreign debt data.

\subsection{Data}

The data is quarterly from 1998Q4 to 2014Q1. Data for macroeconomic variables, GDP, consumption, total investment, private investment, public investment, government spending and exports are obtained from the Turkish Statistical Institute ${ }^{8}$. Data in Turkish lira is converted into U.S. dollars using exchange rates. Foreign debt data is obtained from the statistical data service, EVDS, of the Central Bank of the Republic of Turkey (CBRT). Turkish current account balance data is obtained from Federal Reserve Economic Data (FRED), a service provided by the Federal Reserve Bank of St. Louis. All variables' logarithms are taken before tests, with the exception of the current account balance. The statistical software package Stata ${ }^{\circledR}$ is used for computations. A summary of variables' statistics is given in the following table:

\footnotetext{
8 “Expenditure on the Gross Domestic Product (at Current Prices)", from http://www.tuik.gov.tr/
} 
Table 2. Summary statistics of variables

\begin{tabular}{r|rrrrr} 
Variable & Obs & Mean & Std. Dev. & Min & Max \\
\hline gdp & 65 & 25.45035 & .5041914 & 24.53218 & 26.0792 \\
cons & 65 & 25.09725 & .5156759 & 24.15716 & 25.73068 \\
govn & 65 & 23.39301 & .5876419 & 22.42985 & 24.18702 \\
ppinv & 65 & 23.82049 & .5608981 & 22.58862 & 24.54126 \\
pubinv & 65 & 22.19441 & .5010481 & 21.2988 & 23.08119 \\
priinv & 65 & 23.59598 & .5872839 & 22.33004 & 24.35201 \\
ex & 65 & 23.98556 & .5342917 & 23.15955 & 24.76771 \\
CAB & 65 & $-6.41 e+09$ & $6.16 e+09$ & $-2.05 e+10$ & $2.08 \mathrm{e}+09$ \\
& & & & & \\
\hline stpubdebt & 65 & 21.56728 & 1.019421 & 18.90681 & 23.67633 \\
stpridebt & 65 & 24.25626 & .6272589 & 23.25882 & 25.44786 \\
ltpubdebt & 65 & 24.91365 & .2809014 & 24.37515 & 25.31836 \\
ltpridebt & 65 & 24.81781 & .7474695 & 23.6261 & 25.78814 \\
stltpub & 65 & 24.96064 & .3067622 & 24.38037 & 25.48356 \\
stltpri & 65 & 25.28059 & .6909051 & 24.29017 & 26.3119
\end{tabular}

$$
\begin{aligned}
& \text { gdp }=\log \text { of gross domestic product } \\
& \text { cons }=\log \text { of consumption } \\
& \text { govn }=\log \text { of government spending } \\
& \text { ppinv }=\log \text { of total investment } \\
& \text { pubinv }=\log \text { of public investment } \\
& \text { priinv }=\log \text { of private investment } \\
& \text { ex }=\log \text { of exports } \\
& \text { CAB }=\text { current account balance } \\
& \text { stpubdebt = short-term public foreign debt } \\
& \text { stpridebt = short-term private foreign debt } \\
& \text { ltpubdebt = long-term public foreign debt } \\
& \text { ltpridebt = long-term private foreign debt } \\
& \text { stltpub = total public foreign debt } \\
& \text { stltpri = total private foreign debt }
\end{aligned}
$$

\subsection{Unit Root Tests}

All variables are tested for stationarity with Dickey-Fuller tests, and it is found that all variables are nonstationary at the first level, I(1). This means that the data is fit for cointegration tests and ready to be used in a vector error correction model.

\subsection{Lag Selection}

The effectiveness of many macroeconomic policies lags. This is called the effectiveness lag in economics. It takes time for a monetary policy, like a reduction in the interest rates; or for a fiscal policy, like an increase in the government spending, to take effect. This is very much true for borrowing money as well. If borrowed funds are spent on physical capital, it takes years for that to show up in GDP or exports data. Therefore, it is critical to choose the right 
number of lags in cointegration analyses. Using methods introduced by Nielsen (2001), the number of lags for each cointegration test is determined. The number of lags used for each test is reported on tables with cointegration results below.

\section{Cointegration}

The concept of cointegration is introduced by Granger (1981) and developed by Engle and Granger (1987). It refers to a linear combination of nonstationary variables of the same order. If nonstationary variables of the same order have long-run economic relationships or they are linked together, like the drunk and her dog in Murray (1994), they are cointegrated. Some examples from economics are: the cointegration between consumption and income in the permanent income hypothesis; money supply and price level in monetary economics; or the nominal exchange rate and foreign to domestic price ratio in international economics. In all these examples, there is a long-running relationship between variables, which makes sense in economic theory.

Similarly, one can expect to observe a long-run and linear relationship between foreign debt data and macroeconomic variables, if foreign debt is used effectively to make a difference in macroeconomic variables. Firms borrow funds to expand their businesses. Therefore, it will not be a surprise to detect a cointegration relationship between long-term foreign debt and investment. Is short-term foreign debt cointegrated with any of the macroeconomic variables, or is current account balance cointegrated with any kind of foreign debt? The answers to such questions are reported in the tables below.

The first group of variables consists of foreign debt data, which are short-term public foreign debt, short-term private foreign debt, long-term public foreign debt, long-term private foreign debt, total public foreign debt and total private foreign debt. These variables are shown on the horizontal axis of the tables. The variables in the second group are GDP, consumption, government spending, total investment, public investment, private investment, exports and current account balance. This group is shown on the vertical axis of the tables.

Flow vs. Stock: The variables in the first group, foreign debt, are stock variables, whilst the variables in the second group, macroeconomic indicators, are flow variables (with the exception of current account balance). After testing data for stationarity using the Dickey-Fuller tests, it is found that the variables under study are nonstationary at the first level as mentioned above.

Even though it is possible to convert foreign debt data into flow variables by taking first differences, a cointegration analysis is only possible between variables which are nonstationary at the same level. Taking the first difference of foreign debt data will transform the series into a stationary series, and this will prevent us from using it in a cointegration analysis.

Furthermore, as is the case for any time series data, macroeconomic data is likely to be nonstationary. Taking GDP as an example, what is being produced this year is closely related to what is being produced last year, the year before and so on. On the other hand, the dependency of borrowed funds in a given year, a flow variable, on what is being borrowed in 
previous years does not have to be strong. But this is not the case for debt stock, where the debt stock today is definitely dependent on the debt stock of previous years. Therefore, GDP and debt stock, which are both history-dependent, are more likely to move together, or cointegrated, than GDP and change in debt, where one is history-dependent and the other is not. Consequently, it is more reasonable to carry a cointegration analysis between macroeconomic variables and debt stock variables.

Cointegrating ranks of corresponding vector error correction models are obtained using Johansen's trace statistic method and Johansen's maximum eigenvalue statistic method. These are based on Johansen's maximum likelihood (ML) estimator of the parameters of the vector error correction model. The results are reported in Tables 3, 4 and 5.

\subsection{Short-Term Foreign Debt}

Table 3. Short-term foreign debt and macroeconomic variables

\begin{tabular}{lcccc}
\hline & \multicolumn{2}{c}{$\begin{array}{c}\text { Short-term Public } \\
\text { Foreign Debt }\end{array}$} & \multicolumn{2}{c}{$\begin{array}{c}\text { Short-term Private } \\
\text { Foreign Debt }\end{array}$} \\
\cline { 2 - 5 } & \# of lags & cointegration? & \# of lags & cointegration? \\
\cline { 2 - 5 } GDP & 2 & $\mathbf{x}$ & 6 & $\mathbf{x}$ \\
Consumption & 2 & $\mathbf{x}$ & 4 & $\mathbf{x}$ \\
Government Spending & 1 & $\mathbf{x}$ & 9 & $\mathbf{x}$ \\
Total Investment & 2 & $\mathbf{x}$ & 6 & $\mathbf{x}$ \\
Public Investment & 1 & $\mathbf{x}$ & 3 & $\mathbf{x}$ \\
Private Investment & 2 & $\mathbf{x}$ & 2 & $\mathbf{x}$ \\
Exports & 1 & $\mathbf{x}$ & 6 & $\mathbf{x}$ \\
Current Account Balance & 2 & $\mathbf{x}$ & 6 & $\mathbf{x}$ \\
\hline
\end{tabular}

Table 3 above concerns the cointegration relationships between short-term foreign debt and macroeconomic variables. As can be seen, short-term foreign debt is not cointegrated with any of the variables. This is not surprising at all, considering the use of short-term debt in an economy. Short-term borrowing is riskier compared to long-term borrowing since it may expose borrowers to liquidity problems more often than the other. None of the macroeconomic variables are cointegrated with foreign debt.

There are studies on the effects of short-term foreign capital on real exchange rates for Turkey. Karpuz and Kiziltan (2014) find a two-way causal relationship between them. Kiran (2007) and Şimşek (2007) find that short-term capital is sensitive to changes in real exchange rates. Direkçi and Kaygusuz (2013) find a similar causal relationship from exchange rates to short-term capital movements. Exchange rates are more volatile than the macroeconomic variables analyzed in this paper. Therefore it is more likely to observe causal relationships between exchange rates and short-term capital movements. Long-term capital, rather than short-term capital, is needed to make a difference in macroeconomic variables, like GDP, 
investment and exports. It is unlikely to observe a cointegration or a causal relationship between a macroeconomic variable and short-term capital. As in cointegration analyses, none of the variables are moving together with short-term foreign debt.

\subsection{Long-Term Foreign Debt}

Starting in the late 70's and early 80's, with advancements in computerization and data transmission, there was an increase in capital movements across the globe. Foreign direct investment, a good measure of long-term capital, played a critical role in the development of many developing countries. Besides playing a role in growth, across-the-border capital movements also allow consumption smoothing against fluctuations in macroeconomic conditions (Lane \& Milesi-Ferretti, 2002). Therefore, the effects of productive long-term capital are expected to show-up in macroeconomic variables. A cointegration analysis will test if this is the case for Turkey.

Table 4. Long-term foreign debt and macroeconomic variables

\begin{tabular}{lcccc}
\hline & \multicolumn{2}{c}{$\begin{array}{c}\text { Long-term Public } \\
\text { Foreign Debt }\end{array}$} & \multicolumn{2}{c}{$\begin{array}{c}\text { Long-term Private } \\
\text { Foreign Debt }\end{array}$} \\
\cline { 2 - 5 } GDP & \# of lags & cointegration? & \# of lags & cointegration? \\
\cline { 2 - 5 } Consumption & 4 & $\mathbf{x}$ & 2 & $\mathbf{x}$ \\
Government Spending & 11 & $\mathbf{x}$ & 2 & $\mathbf{x}$ \\
Total Investment & 11 & $\checkmark$ & 8 & $\checkmark$ \\
Public Investment & 5 & $\mathbf{x}$ & 2 & $\mathbf{x}$ \\
Private Investment & 1 & $\mathbf{x}$ & 8 & $\mathbf{x}$ \\
Exports & 5 & $\checkmark$ & 2 & $\checkmark$ \\
Current Account Balance & 1 & $\mathbf{x}$ & 4 & $\mathbf{x}$ \\
\hline
\end{tabular}

Table 4 reports cointegration relationships between long-term foreign debt and macroeconomic variables. In the long-run, government spending is cointegrated with both public and private foreign debt. The cointegration between public foreign debt and government spending raises the question of whether the Turkish government has pursued deficit spending in the given period. Many governments around the world engaged in different forms of aggressive deficit spending after the 2008 global financial crisis (Foster, 2009). Turkish public foreign debt in the period following the 2008 crisis is more or less stable, as seen in Figure 1, but it departed from its long-run trend of a decline.

Another result from Table 4 is the fact that long-term private foreign debt is cointegrated with private investment. This is not a surprising result considering the fact that Turkey's domestic savings rate is as low as fourteen percent as of 2012, Table 1. Therefore, Turkey has to finance its investment through foreign borrowing, which is the exact same conclusion seen in the table above. 
The facts that long-term public foreign debt is cointegrated with private investment but not with public investment, and long-term private foreign debt is cointegrated with government spending are somewhat surprising. It looks like the government and the private sector both benefit from long-term borrowing opportunities together that enables them to do better in the long-run.

\subsection{Public and Private Foreign Debt}

Short-term or long-term borrowing allows expansion in macroeconomic variables. In this section, macroeconomic variables that are cointegrated with total public or total private foreign debt are explored. Cointegration results are reported in Table 5. In this table, it is seen that total private foreign debt is cointegrated with all of the macroeconomic variables under consideration, except for the current account balance. Total public foreign debt is cointegrated only with government spending and with public investment.

Table 5. Public vs. private foreign debt and macroeconomic variables

\begin{tabular}{lcccc}
\hline & \multicolumn{2}{c}{ Total Public Foreign Debt } & \multicolumn{2}{c}{ Total Private Foreign Debt } \\
\cline { 2 - 5 } & \# of lags & cointegration? & \# of lags & cointegration? \\
\cline { 2 - 5 } GDP & 1 & $\mathbf{x}$ & 1 & $\checkmark$ \\
Consumption & 11 & $\mathbf{x}$ & 2 & $\checkmark$ \\
Government Spending & 10 & $\checkmark$ & 1 & $\checkmark$ \\
Total Investment & 5 & $\mathbf{x}$ & 2 & $\checkmark$ \\
Public Investment & 10 & $\checkmark$ & 2 & $\checkmark$ \\
Private Investment & 5 & $\mathbf{x}$ & 2 & $\checkmark$ \\
Exports & 1 & $\mathbf{x}$ & 1 & $\checkmark$ \\
Current Account Balance & 2 & $\mathbf{x}$ & 6 & $\mathbf{x}$ \\
\hline
\end{tabular}

These results suggest that private foreign borrowing has broader implications than public foreign borrowing. The private sector's foreign borrowing, which is cointegrated with almost all macroeconomic variables, plays a vital role in the Turkish economy. GDP, consumption, government spending, investment and exports are all critically dependent upon foreign borrowing.

This conclusion begs the question of whether the Turkish economy is vulnerable to adverse developments in international financial markets. A hawkish view may suggest reducing Turkey's exposure to the volatilities of global markets. But such measures will also reduce Turkey's opportunity to grow faster than it could on its own. Global liquidity can be taken as an opportunity to all developing countries of the world, as long as borrowed funds are invested properly to improve future output. Turkey is only one of the developing countries that is taking advantage of low global interest rates, mainly those of the United States.

From Tables 3, 4 and 5, it is seen that the current account balance is not cointegrated with any of the foreign debt variables. Karaman and Can (2014) argue that the most important 
determinant of the current account balance for Turkey is global interest rates or global liquidity glut. Turkish private sector keeps borrowing money from international financial markets as long as it is available and cheap. Therefore, the main cause of Turkey's current account deficit is not any of its domestic variables, but the conditions of international financial markets. In this study, no correlations between the current account deficit and foreign debt are found, which confirms the finding of Karaman and Can (2014).

Another finding is the fact that government spending is cointegrated with total public foreign debt, total private foreign debt, long-term public foreign debt and long-term private foreign debt. This means that it is cointegrated with all kinds of foreign debt, except for the short-term foreign debt. Together with the fact that government spending and public investment are cointegrated with total public foreign debt, they imply that the Turkish public sector is heavily integrated with foreign financial markets when it comes to government spending. This conclusion requires further analysis, which is beyond the scope of this paper. Besides this, GDP, consumption, total investment and exports are only cointegrated with total private foreign debt and nothing else. These results confirm the critical role of foreign borrowing in the growth of a developing country like Turkey.

\section{Granger-Causal Relations}

A cointegration implies a long-run and linear equilibrium relationship between variables (Kennedy, 2003) but a cointegration test is not enough to determine a Granger-causality between these variables. Hence, vector error correction (VEC) models are used to check for causality. VEC models are setup, as described in Johansen (1995), for the variables with existing cointegration relations, which are 13 in total. The same lag values used in cointegration analyses are used for VEC models. Interesting results ensued. In the following table, Table 6, the VEC model between exports and total private foreign debt is reported. As a reminder: "ex" stands for exports and "stltpri”" stands for total private foreign debt.

In Table 6, it is seen that the coefficient for the error term of total private foreign debt $(-0.1429 .$.$) is negative and significant. This means that there is a long-run causal relationship$ from exports to total private foreign debt. The absolute value of this number, 0.14 , represents the speed of adjustment when the two variables are decoupled from each other. It is a relatively small number for these variables to converge to their long-run paths. Since the short-term coefficients are insignificant, there is no short-term relationship between exports and total private foreign debt. In the cointegration equation, the coefficient of exports $(-1.327 .$.$) is significant, which confirms the result that exports are effective in the$ determination of total private foreign debt level.

In Table 7, the remaining causal relationships are reported ${ }^{9}$. From the table, it is seen that GDP, consumption, government spending, total investment and private investment all precede total private foreign debt. This implies that increases in GDP, consumption, government

\footnotetext{
9 For the sake of saving space, detailed statistical reports of all of the 13 VEC models are not included, but the Granger-causality relationships are given in Table 7 .
} 
spending, total investment and private investment cause Turkish foreign debt to rise ${ }^{10}$. This implies that development is causing growth in debt for Turkey.

Table 6. Vector Error Correction Model for Exports and Total Private Foreign Debt

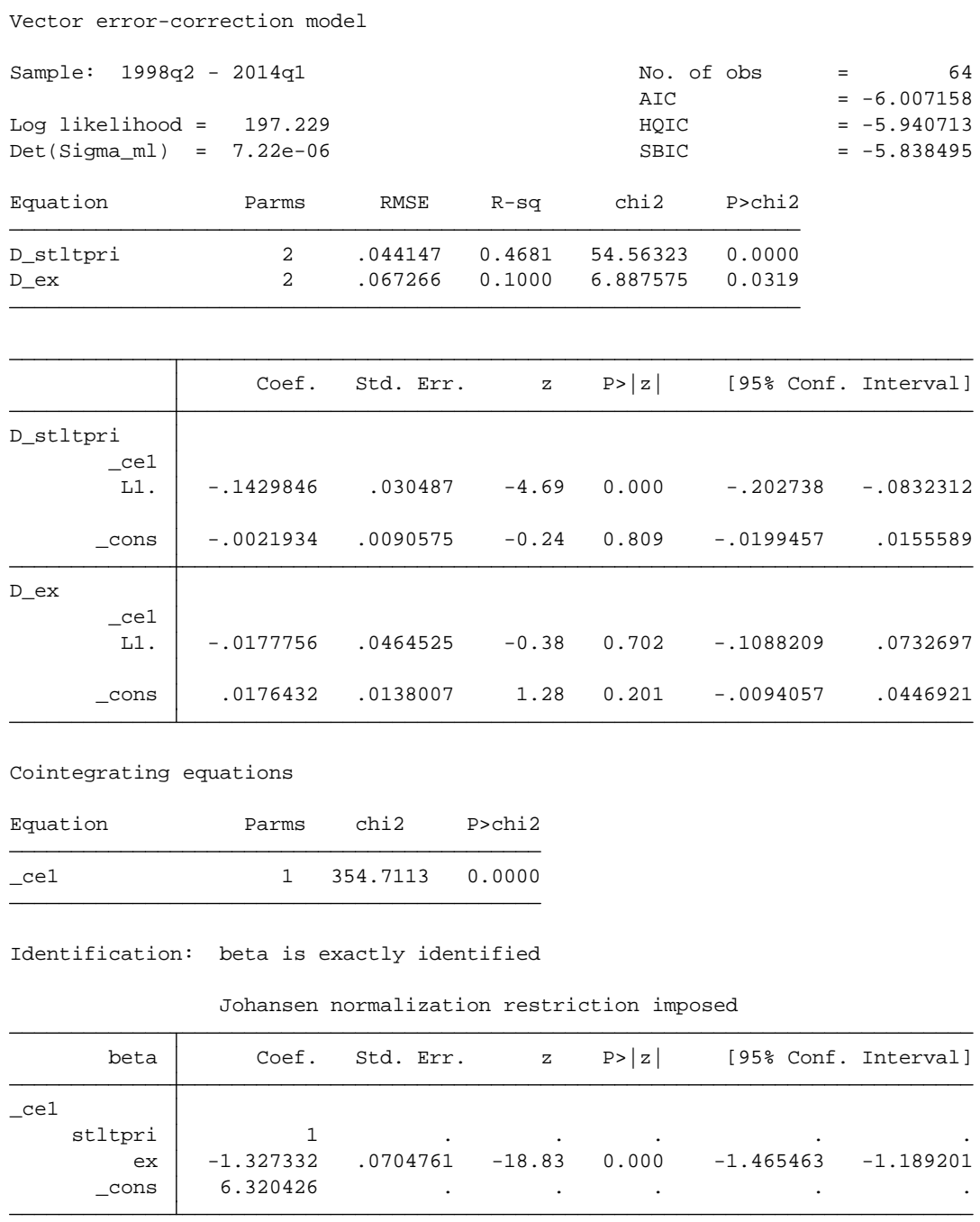

One should keep in mind that Granger causality does not actually mean a causal relationship, but is about the timing and the correlation of the variables under study (Zaman, 2009). Therefore, the variables are named as preceding and following variables in Table 7. In lines 8 through 13, macroeconomic variables precede total private foreign debt. The other possibility is foreign debt Granger-causing increases in macroeconomic variables, which may signal a debt-driven growth. For the variables in lines 8 through 13, Granger causality analyses are supporting a growth-driven increase in foreign debt; the better one of the two possibilities.

$\overline{10}$ Just like exports cause total private foreign debt to rise, as discussed before. 
Table 7. Granger-Causal Relations

\begin{tabular}{ccc}
\hline & Preceding Variable & Following Variable \\
\hline 1 & Long-term Public F. Debt & Government Spending \\
2 & Government Spending & Long-term Private F. Debt \\
3 & Long-term Public F. Debt & Private Investment \\
4 & Private Investment & Long-term Private F. Debt \\
5 & Total Public F. Debt & Government Spending \\
6 & Total Public F. Debt & Public Investment \\
7 & Total Private F. Debt & Public Investment \\
8 & GDP & Total Private F. Debt \\
9 & Consumption & Total Private F. Debt \\
10 & Government Spending & Total Private F. Debt \\
11 & Total Investment & Total Private F. Debt \\
12 & Private Investment & Total Private F. Debt \\
13 & Exports & Total Private F. Debt \\
\hline
\end{tabular}

In lines 1, 5 and 6 in Table 7, long-term public foreign debt and total public foreign debt precedes government spending, which differs from the fact that private sector macroeconomic variables follow foreign debt (lines 8 through 13). One way to interpret this result is the private sector's willingness to borrow only after observing improvements in macro variables where government borrows first and spends later. Government is inflicted with debt-driven growth since its foreign debt data precedes its macroeconomic variables where the private sector's macroeconomic variables improve with or before its foreign debt stock. Debt-driven growth is a popular topic considering the fact that after the 2008 world financial crisis, big economies like the U.S. and China utilized deficit spending policies, which opened the discussion of whether growth was being achieved with excessive debt (Caruana, 2014).

Another observation is the fact that public foreign debt precedes private investment (line 3). This is a result parallel with Keynesian economics: increases in government spending cause improvements in the economy, like increases in private investment. Long-term private foreign debt does not precede any macroeconomic variable but follows government spending and private investment (lines $2 \& 4$ ). However, the total private foreign debt precedes public investment (line 7).

\section{Conclusion}

Countries' long-term economic development can be achieved only with a sound financial system. With developed financial markets, people find the opportunity to convert their knowledge, skills and entrepreneurship into material outcomes. The other side of the coin of borrowing money is debt. Today, Turkey's foreign debt is growing faster than its economy. Similar arguments can be made for China and some other countries as well. Then the question becomes whether growing debt levels are sustainable or not. Ultimately, financial 
markets are outcomes of their countries' political systems (Calomiris \& Haber, 2014). The political systems' attitude towards debt, whether the system is content with it or not, determines the action plan (including the laissez faire plan) for growing levels of foreign debt. Although Turkey is reducing its public debt, it is allowing its private sector to increase its exposure to growing levels of debt denominated in foreign currency. After the 2008 global crisis, China has opened its gates to more borrowing in order to avoid or lessen the effects of this crisis. Currently, the stock of credit in China is more than $200 \%$ of its GDP, and people have started to speculate on another global crisis that would be triggered by China's growing levels of debt.

Debt matters, as discussed in this paper. Considerable evidence of this statement is the cointegration, or the long-run equilibrium relationship, between Turkish foreign debt and its macroeconomic variables. It would not be surprising to see similar cointegration relationships for other developing countries as well. For Turkey, GDP, consumption, government spending, total investment, public investment, private investment and exports are cointegrated with total private foreign debt. Government spending and public investment are cointegrated with total public foreign debt.

Future Research: One of the results found in this paper is the fact that the public sector and the private sector borrow differently. The private sector borrows only after improvements in macroeconomic variables, whereby the public sector borrows before increases in public spending. Private sector's spending scheme suggests that its spending is procyclical with business cycles. Public sector's spending scheme hints at a debt-driven spending for the government. This finding requires further analyses that will look into the details of how the Turkish government borrows and spends money. A widely used assumption in economics is that governments are the safest debtors. A government may utilize this feature to its benefit and avoid careful planning in its borrowing decisions, compared to the private sector. Insolvency is always a possibility and a threat for the private sector, but it is of less concern to a government.

Although borrowing money is essential for growth, at what point debt will be overwhelming rather than expansionary is a difficult question to answer. Today, where the expansionary monetary policies of countries like the U.S., European Union, China and Japan are trying to stimulate private borrowing, the question of how much debt to take is important. In the period after the 2008 global crisis, many countries piled up their debt stock for the sake of reviving their creeping economies. It used to be Japan alone, as an example of a country where monetary policy is not working as expected. Today, Japan is accompanied by others in trying to inflate private borrowing. The world is about to witness the outcomes of expansionary monetary policies at a macro scale, as never seen before.

\section{References}

Ahmad, M. M. (2003). Distant voices: the views of the field workers of NGOs in Bangladesh on microcredit. The Geographical Journal, 169(1), 65-74.

Azariadis, C. (1993). Intertemporal macroeconomics: Blackwell Oxford. 
Bernanke, B. S. (2005). The global saving glut and the US current account deficit. Board of Governors of the Federal Reserve System (US) Speech(Mar 10).

Bernheim, B. D. (1988). Ricardian equivalence: An evaluation of theory and evidence: National Bureau of Economic Research Cambridge, Mass., USA.

Bredenkamp, H., Josefsson, M., \& Lindgren, C.-J. (2009). Turkey's Renaissance: From Banking Crisis to Economic Revival. Brau, E. et I. McDonald, Successes of the International Monetary Fund: Untold Stories of Cooperation at Work, Palgrave Macmillan.

Bulutay, T. (2015). Büyüme Üzerine Düşünceler [Thoughts on Growth]. Turkish Economic Association Discussion Paper 2015/3

Calomiris, C. W., \& Haber, S. H. (2014). Fragile by Design: The Political Origins of Banking Crises and Scarce Credit: Princeton University Press.

Caruana, J. (2014). Debt trouble comes in threes. International Finance Forum 2014 Annual Global Conference.

Conway, E. (2010). Did Goldman Sachs help Britain hide its debts too? Retrieved May 8, 2015, from http://blogs.telegraph.co.uk/finance/edmundconway/100003757/did-goldmansachs-help-britain-hide-its-debts-too/

Dichter, T. W., Harper, M., \& Action, P. (2007). What's wrong with microfinance? : Practical Action Publishing Warwickshire.

Direkçi, T. B., \& Kaygusuz, S. (2013). Kisa Vadeli Sermaye Hareketlerinin Makroekonomik Değişkenler İle Olan Etkileşimi: Türkiye Örneği [Short Term Capital Movements, The Interaction Between Macroeconomic Variables: The Case Of Turkey]. Journal of Academic Researches and Studies, 5(9).

Engle, R. F., \& Granger, C. W. J. (1987). Cointegration and Error Correction - Representation, Estimation, and Testing. Econometrica, 55(2), 251-276. http://dx.doi.org/10.2307/1913236

Foster, J. (2009). Keynesian Fiscal Stimulus Policies Stimulate Debt--Not the Economy. Backgrounder, 2302.

Granger, C. W. J. (1981). Some Properties of Time-Series Data and Their Use in Econometric-Model Specification. Journal of Econometrics, 16(1), 121-130. http://dx.doi.org/10.1016/0304-4076(81)90079-8

Johansen, S. (1995). Likelihood-based inference in cointegrated vector autoregressive models. OUP Catalogue.

Karaman, S. C., \& Can, N. (2014). The Effects of World Financial Integration on Financing Current Account Deficits: The Case for Turkey. International Journal of Academic Research in Business and Social Sciences, 4(10), 144-157. http://dx.doi.org/10.6007/IJARBSS/v4-i10/1214

Karaman, C. S. (2015). International Financial Markets during Özal Era and Today, A Comparative Analysis. Under Review. 
Karpuz, F., \& Kızıltan, A. (2014). Türkiye'de Kisa Vadeli Yabanci Yatirimlar İle Reel Döviz Kuru Arasindaki İlişki [The Relationship Between Short Term Investments and Real Exchange Rate in Turkey]. Ekev Akademi Dergisi, 18(60), 197-210.

Kennedy, P. (2003). A guide to econometrics: MIT press.

Kıran, B. (2007). Türkiye'de Reel Döviz Kuru İle Kisa Ve Uzun Vadeli Sermaye Hareketleri İlişkisi [The Relationship between Real Exchange Rates and Short-term/Long-term Capital Movements in Turkey]. Marmara Üniversitesi, I.I. B.F. Dergisi, 12(1), 269-283.

Lane, P. R., \& Milesi-Ferretti, G. M. (2002). Long-term capital movements NBER Macroeconomics Annual 2001, Volume 16 (pp. 73-136): MIT Press.

Minsky, H. P. (1974). The modeling of financial instability: An introduction. Modelling and Simulation, 5(1), 267-272.

Murray, M. P. (1994). A Drunk and Her Dog - an Illustration of Cointegration and Error-Correction. American Statistician, 48(1), 37-39. http://dx.doi.org/10.2307/2685084

Nielsen, B. (2001). Order determination in general vector autoregressions.

Peacock, R. (2000). Failure and assistance of small firms. Understanding Small Business Website. Retrieved July 5, 2010, from www. sbeducation. info/downloads/sbfail.pdf

Romer, D. (2011). Advanced macroeconomics. McGraw-Hill/Irwin.

Seater, J. J. (1993). Ricardian equivalence. Journal of Economic Literature, 142-190.

Şanl1, F. B., \& Aksöz, H. (2014). 1980 Sonrasi Türkiye'de Diş Borçlanma Üzerinde Yurtiçi Tasarruflarin Etkisinin Analizi [The Effects of Domestic Savings on Foreign Financing in Turkey after 1980]. Finansal Araştırmalar ve Çalışmalar Dergisi, 6(11), 83-98.

Şimşek, A. R. (2007). Kisa Vadeli Sermaye Hareketleri Ve Türkiye Ekonomisine Etkileri.

Thomas, L. Jr. (2014). 'Fragile Five' Is the Latest Club of Emerging Nations in Turmoil. Retrieved March 25, 2015, from http://www.nytimes.com/2014/01/29/business/international /fragile-five-is-the-latest-club-of-emerging-nations-in-turmoil.html?_r=0

Went, R. (2000). Globalization: Neoliberal challenge, radical responses: Pluto Press.

Zaman, A. (2009). Causal Relations via Econometrics. International Econometric Review, 2(1), 36-56.

\section{Copyright Disclaimer}

Copyright for this article is retained by the author(s), with first publication rights granted to the journal.

This is an open-access article distributed under the terms and conditions of the Creative Commons Attribution license (http://creativecommons.org/licenses/by/3.0/). 